\title{
Discovery of novel haplotypes from wild populations of Kappaphycus (Gigartinales, Rhodophyta) in the Philippines
}

\author{
Michael Y. Roleda ${ }^{1, *}$, Zae-Zae A. Aguinaldo ${ }^{1}$, Bea A. Crisostomo ${ }^{1}$, Lourie Ann R. Hinaloc ${ }^{1}$, \\ Vicenta Z. Projimo ${ }^{2}$, Richard V. Dumilag ${ }^{3}$ and Arturo O. Lluisma ${ }^{1}$ \\ ${ }^{1}$ The Marine Science Institute, University of the Philippines, Diliman 1101, Quezon City, Philippines \\ ${ }^{2}$ Department of Agriculture, Bureau of Fisheries and Aquatic Resources Regional Office No. 8, Marasbaras 6500, Tacloban \\ City, Leyte, Philippines \\ ${ }^{3}$ Institute of Oceanography and Environmental Science, Mindanao State University-Tawi-Tawi College of Technology and \\ Oceanography, Boheh Sallang, Sanga-Sanga, Bongao 7500, Tawi-Tawi, Philippines
}

As the global demand for the carrageenophyte Kappaphycus is steadily increasing, its overall productivity, carrageenan quality, and disease resistance are gradually declining. In the face of this dilemma, wild Kappaphycus populations are viewed as sources of new cultivars that could potentially enhance production; therefore, assessment of their diversity is crucial. This study highlights the morphological and genetic diversity of wild Kappaphycus species obtained from two sites in the Philippines. Nucleotide alignments of available $5^{\prime}$ region of the mitochondrial cytochrome $c$ oxidase subunit I (COI-5P) and cox2-3 spacer sequences of Kappaphycus confirmed the presence of K. alvarezii in Guiuan, Eastern Samar and K. striatus in Bolinao, Pangasinan. Based on the concatenated sequences of the COI-5P and the cox2-3 spacer, nine novel haplotypes were observed along with other published haplotypes. However, there was no relationship between haplotype and morphology. These newly recognized haplotypes indicate a reservoir of unutilized wild genotypes in the Philippines, which could be taken advantage of in developing new cultivars with superior traits. DNA barcodes generated from this study effectively expand the existing databank of Kappaphycus sequences and can provide insights in elucidating the genetic diversity of Kappaphycus species in the country.

Key Words: DNA barcoding; eucheumatoid; genetic diversity; haplotype; Kappaphycus alvarezii; Kappaphycus striatus

\section{INTRODUCTION}

The eucheumatoid seaweed of the genus Kappaphycus Doty (Gigartinales, Rhodophyta) has been the major raw material source for $\kappa$-carrageenan production worldwide and their farming has become an important alternative livelihood in many coastal communities for decades (Ask and Azanza 2002, Bixler and Porse 2011). Kappaphycus alvarezii (Doty) L. M. Liao ('Cottonii') and Kappaphycus striatus (F. Schmitz) L. M. Liao ('Sacol') are two of the most widely cultivated Kappaphycus species. They were introduced to over 30 countries worldwide (Bixler and Porse 2011, Valderrama et al. 2013) since their successful cultivation was pioneered in the Philippines (Doty 1973, Parker 1974, Trono 1974). Kappaphycus farming had spread all over the Philippines, with major farming sites in Sulu, Tawi-Tawi, Zamboanga provinces, southern Palawan, and the Bohol-Leyte Central Visayas Re-
(9) \$ This is an Open Access article distributed under the terms of the Creative Commons Attribution Non-Commercial License (http://creativecommons.org/licenses/by-nc/3.0/) which permits unrestricted non-commercial use, distribution, and reproduction in any medium, provided the original work is properly cited.
Received August 14, 2020, Accepted February 18, 2021

*Corresponding Author

E-mail: myroleda@up.edu.ph

Tel: +63-2-922-3962, Fax: +63-2-924-7678 
gion (Valderrama et al. 2013, Trono and Largo 2019). The Philippines had been the major producer of cultivated Kappaphycus until its production declined in 2008. This decline can be attributed to outbreaks of ice-ice disease and epiphyte infestation, which are exacerbated by environmental stressors, e.g., increase in sea surface temperature, and destruction caused by seasonal typhoons (Vairappan et al. 2008, Valderrama et al. 2015, Largo et al. 2017).

To enhance Kappaphycus production, several studies have been conducted to improve the quality of the original seedstocks using micropropagation technique (e.g., Hurtado and Cheney 2003, Hurtado and Biter 2007, Yunque et al. 2011, Luhan and Mateo 2017) and protoplast culture (Salvador and Serrano 2005). Despite these advancements, seaweed farmers still mainly rely on vegetative propagation (via thallus cuttings) for every cropping cycle. Since the original seedstocks were sourced from a few genotypes, their continuous vegetative propagation resulted in the low genetic diversity of the cultivars (Zuccarello et al. 2006, Halling et al. 2013). To sustain the carrageenan industry, it is essential to generate or discover new strains / seedstocks from the wild (e.g., AzanzaCorrales and Ask 2003, Luhan and Sollesta 2010, Roleda et al. 2017).

There has been a continuous decrease in the overall productivity, reduction in carrageenan yield and quality, and increased susceptibility to diseases among Kappaphycus and other eucheumatoid cultivars, not only in the Philippines but also elsewhere (Hayashi et al. 2017, Valero et al. 2017). The practice of monoculture (i.e., the farming of crops with identical genetic backgrounds) increases the susceptibility of farms to disease outbreaks since once a pathogen has evolved to attack a particular genotype, genetic homogeneity among crops leads to no genetic resistance. Thus, the seaweed industry could greatly benefit from increasing crop genetic diversity, which has been shown to be a robust defense against infections (Ekroth et al. 2019).

One way to improve a domesticated crop's genetic diversity is through the incorporation of genes from wild relatives (Harlan and de Wet 1971, Maxted et al. 2006). The transmission of genes from wild relatives can greatly improve biotic and abiotic stress resistance of domesticated land crops, as well as confer desirable traits such as improved yield and nutritional content (Li et al. 2007, Xie et al. 2008, Prischmann et al. 2009, Munns et al. 2012, Zhang et al. 2017). Similar strategies can be applied to the seaweed industry, whether via cultivation of novel wild haplotypes, breeding programs, or genetic modification
(Ask and Azanza 2002, Robinson et al. 2013, Roleda et al. 2017). For this purpose, biodiversity assessment of wild populations is important to select a pool from which individuals with desirable traits could be selected.

Taxonomic surveys of wild Philippine Kappaphycus populations had been conducted even before its first successful cultivation in the late 1960s (Doty 1973, Parker 1974, Trono 1974). More recent studies have recognized several wild genotypes in some areas (e.g., Eastern Samar, Guimaras, Ilocos Norte, Sorsogon, and Tawi-Tawi) (Tan et al. 2012, Lim et al. 2014, Dumilag et al. 2016a, 2017). Although several studies on Philippine Kappaphycus diversity have been published (Dumilag and Lluisma 2014, Lim et al. 2014, Dumilag et al. 2016a, 2016b, 2017), current knowledge on wild Kappaphycus spp. diversity is limited to a few localities in the Philippines. It is therefore of interest to examine wild Kappaphycus specimens in other regions of the country to assess the presence of additional novel genotypes.

In this study, the diversity of wild Kappaphycus species in Guiuan, Eastern Samar and Bolinao, Pangasinan, sites with known records of wild Kappaphycus (Trono and Ohno 1992, Aguilan et al. 2003, Dumilag et al. 2016a) and known fertile plants (Ganzon-Fortes 2016, Hinaloc 2017, Rodrigora 2017, Roleda et al. 2017), was assessed based on the analysis of the 5 ' region of the mitochondrial cytochrome $c$ oxidase subunit I gene (COI-5P) and the cox2-3 intergenic spacer sequences in tandem with phenotypic descriptions. Comparative analysis of newly generated sequences to existing Kappaphycus haplotypes (wild and farmed) was also performed.

\section{MATERIALS AND METHODS}

\section{Sample collection}

A total of 71 wild Kappaphycus specimen were collected in the coastal waters of Bolinao, Pangasinan (Northern Philippines) (Malilnep: 16²6'14.45" N, 119 56'36.72" E; Silaki Islet reef flat: $16^{\circ} 26^{\prime} 22.20^{\prime \prime} \mathrm{N}, 119^{\circ} 55^{\prime} 46.60^{\prime \prime} \mathrm{E}$ ) (Fig. 1A) and Guiuan, Eastern Samar (Central Philippines) $\left(10^{\circ} 56^{\prime} 41.40^{\prime \prime} \mathrm{N}, 125^{\circ} 44^{\prime} 13.80^{\prime \prime}\right.$ E) (Fig. 1B) by snorkeling in $<1 \mathrm{~m}$ depth during low tide. The Malilnep site is a 3 $\mathrm{m}$ deep reef flat with hard coralline substrate exposed to strong surf and currents. In contrast, the subtidal area around the coralline sandbar in Guiuan has relatively calm waters.

The habit of each specimen was documented using a DSLR camera and a ruler to record measurements. 


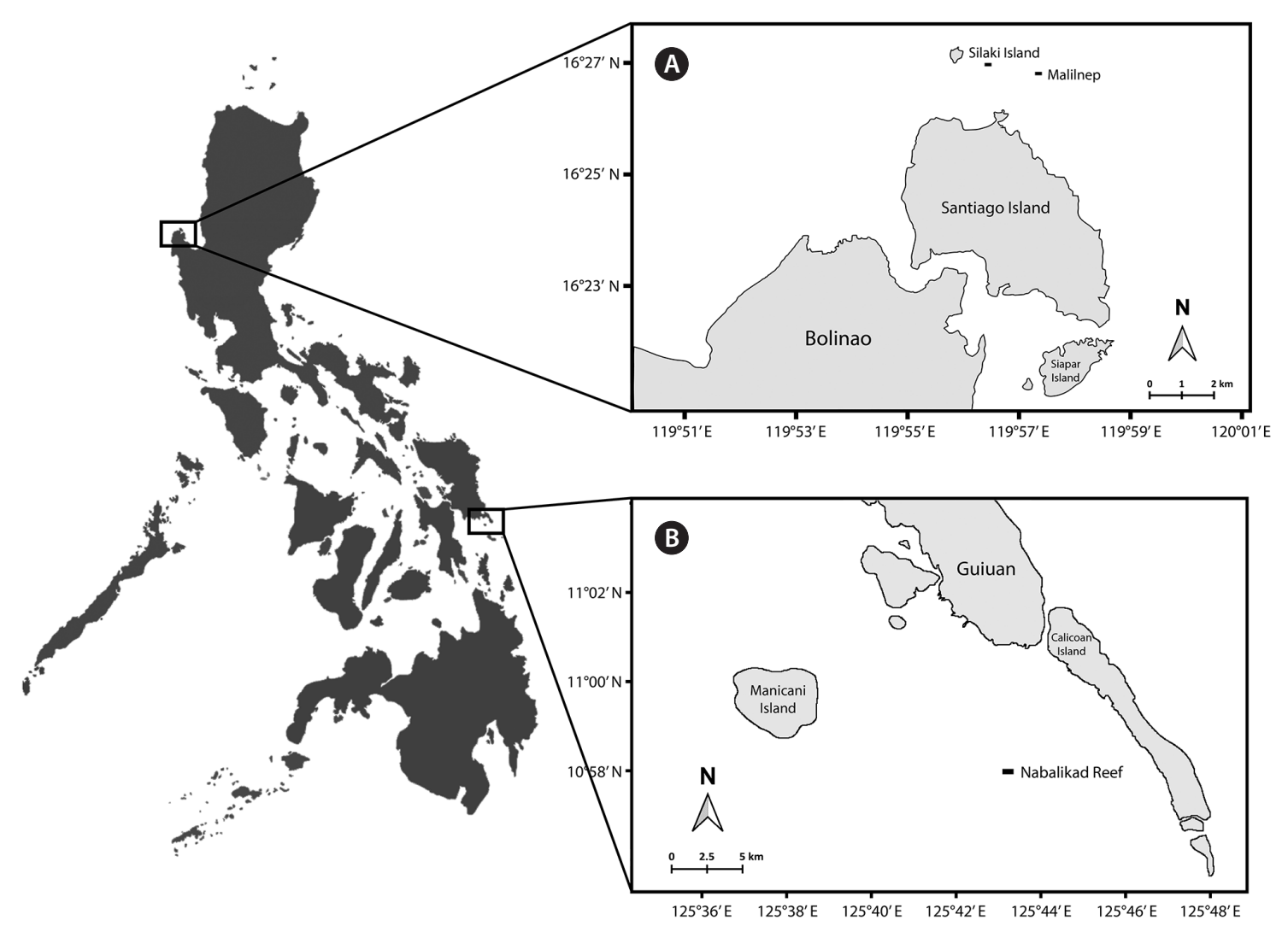

Fig. 1. Sampling locations of wild Kappaphycus specimens in Bolinao, Pangasinan (A) and Guiuan, Eastern Samar (B), Philippines.

A small portion of thallus (approximately $2-3 \mathrm{~cm}$ of thallus apex) was excised and preserved in absolute ethanol (95\%) for DNA barcoding. Voucher specimens were kept at the Gregorio T. Velasquez Phycological Herbarium, The Marine Science Institute, University of the Philippines, Diliman, Quezon City, Philippines. Summarized information of all collected samples is listed in Supplementary Table S1.

\section{Morphological characterization}

Gross morphology of collected wild specimens was recorded, focusing on the branching patterns, color, and texture of the thalli. Preliminary species identification was done based on morphological descriptions (Doty 1985, 1988).

\section{DNA extraction and PCR amplification}

Seaweed materials were homogenized in mortar and pestle using liquid nitrogen until pulverized. About 15-20 mg of each pulverized sample was used for DNA isolation. Genomic DNA was extracted using a DNeasy Plant
Mini Extraction Kit (Qiagen, Hilden, Germany) following the manufacturer's instructions. Extracted DNA samples were stored at $-20^{\circ} \mathrm{C}$.

The COI-5P and cox2-3 intergenic spacer were used as markers because these are more abundant in the GenBank database compared to other markers (cox2, $r b c \mathrm{~L}$, and 18S rRNA gene). The COI-5P sequence was amplified using the primers GazF1 and GazR1 (Saunders 2005), while the cox2-3 intergenic spacer region was amplified using the primers cox2-for and cox3-rev (Zuccarello et al. 1999). PCR reactions were prepared in $50 \mu \mathrm{L}$ volumes composed of the following: $1 \times$ Taq Master Mix reagent (Vivantis, Selangor, Malaysia), $0.4 \mu \mathrm{M}$ of each primer (Zuccarello et al. 1999), and $1 \mu \mathrm{L}$ of template DNA. Amplification was performed in Veriti 96-well (Applied Biosystems, Foster City, CA, USA) with the following conditions: $94^{\circ} \mathrm{C}$ for $4 \mathrm{~min} ; 5$ cycles of $93^{\circ} \mathrm{C}$ for $1 \mathrm{~min}, 45^{\circ} \mathrm{C}$ annealing for $1 \mathrm{~min}, 72^{\circ} \mathrm{C}$ extension for $1 \mathrm{~min}$; followed by 30 cycles of $93^{\circ} \mathrm{C}$ for $30 \mathrm{~s}, 50^{\circ} \mathrm{C}$ annealing for $30 \mathrm{~s}, 72^{\circ} \mathrm{C}$ extension for $30 \mathrm{~s}$, and followed by $72^{\circ} \mathrm{C}$ final extension for $5 \mathrm{~min}$. Amplicons were sent to Macrogen Inc. (Seoul, Korea) for purification and Sanger sequencing (bidirectional). 


\section{Phylogenetic and haplotype network analyses}

Three separate datasets (COI-5P, cox2-3 spacer, and concatenated COI-5P-cox2-3 spacer) were used for haplotype network and phylogenetic analyses. Chromatogram sequences were checked and edited, and contiguous sequences were assembled using DNABaser version 5.15 (Heracle Biosoft, Argeș, Romania). Sequence alignments were generated using the ClustalW (Thompson et al. 1994) using MEGA ver. 7 (Kumar et al. 2016). Additional COI-5P and cox2-3 spacer sequences, representing both wild and farmed specimens from NCBI were included in the final dataset following the haplotype nomenclature of Dumilag et al. (2016a). Sequences were trimmed to match the lengths of the shortest sequence.

Statistical parsimony analyses of Kappaphycus haplotypes were performed using TCS ver. 1.23 (Clement et al. 2000). Gaps were set as missing characters and connection limits were determined and fixed based on the resulting networks.

For phylogenetic analyses, Kappaphycus cottonii was included in the final alignment as an outgroup. Maximum likelihood analyses were then run in MEGA using Tamura 3-parameter (Tamura 1992) substitution model with 1,000 bootstrap replications. All phylograms can be found in the supplementary material (Supplementary Figs S1-S3).

\section{RESULTS}

\section{Morphological characterization of wild Kappa- phycus samples}

Preliminary identifications of the wild Kappaphycus samples based on gross morphology were ascribed to $K$. alvarezii (Guiuan, Eastern Samar) or K. striatus (Bolinao, Pangasinan). Morphological features of all specimens barcoded in this study are described in the Supplementary Table S2. Photographs representing distinct morphotypes for each species are shown in Fig. 2.

\section{Kappaphycus alvarezii}

In the subtidal area around the coralline sandbar in Guiuan, K. alvarezii were found attached to hard coralline substrate covered with layers of loose, fine, or coarse sand. Overall texture of the thalli is fleshy, cartilaginous, and pliable. Thalli surface is slightly uneven and glossy. Color morphotypes vary from green (Fig. 2B), brown (Fig.
2C), red (Fig. 2D), and shades in between. Thirteen individuals showed multicolored pigmentation (i.e., a combination of green, brown, and red colors as shown in Fig. 2A). Thalli are erect, up to $60 \mathrm{~cm}$ long. Branching pattern is pinnate, irregular, and dichotomous in some. Branchlets are tapered towards the apex and apices are slender, round, or pointed. Different life history stages were observed: female gametophyte with cystocarp (3), male gametophyte (10), tetrasporophyte (22), and life-historyambiguous vegetative plants (3).

\section{Kappaphycus striatus}

In Malilnep, the wild populations of $K$. striatus were found encrusting on the coralline substrates, sometimes camouflaged by overlying dense cover of other macroalgal species or found attached on coralline rubbles among patches of seagrasses. Relative to wave exposure, Карраphycus exposed to moderate water motion in Guiuan exhibit upright growth forms; whereas the plants exposed to strong water movement and heavy grazing pressure in Malilnep exhibited prostrate growth forms (Fig. 2E, G \& $\mathrm{H})$.

Thalli surface is rough, uneven, and mostly covered with dense protrusions (Fig. 2E-H). Color does not vary as much as in K. alvarezii from Guiuan. Thalli color ranges from shades of yellowish green (Fig. 2F), yellowish brown (Fig. 2G \& H), to dark brown (Fig. 2E). Habit is decumbent forming clumps measuring $10-30 \mathrm{~cm}$. Holdfasts are inconspicuous ventral haptera. Branching is irregular and indeterminate with blunt to conical apices. Different life history stages observed were: female gametophyte with cystocarp (5), male gametophyte (1), and life-historyambiguous vegetative plants (24).

\section{Molecular confirmation and haplotype analysis}

The phylograms constructed from three datasets (COI-5P, cox2-3 spacer, and concatenated COI-5P-cox2-3 spacer) were found to be congruent with previous studies (Tan et al. 2013, Lim et al. 2014, Dumilag et al. 2016a) and confirmed the genetic identities of our Kappaphycus samples. All samples from Guiuan, Eastern Samar were genetically identified as $K$. alvarezii $(\mathrm{n}=41)$, whereas those from Bolinao, Pangasinan were all identified as $K$. striatus $(\mathrm{n}=30)$.

The sampled wild $K$. alvarezii and $K$. striatus were distributed into five and three COI-5P haplotypes, respectively (Supplementary Fig. S4). Three K. alvarezii sequences were identical to KALV-C, which was also report- 
A

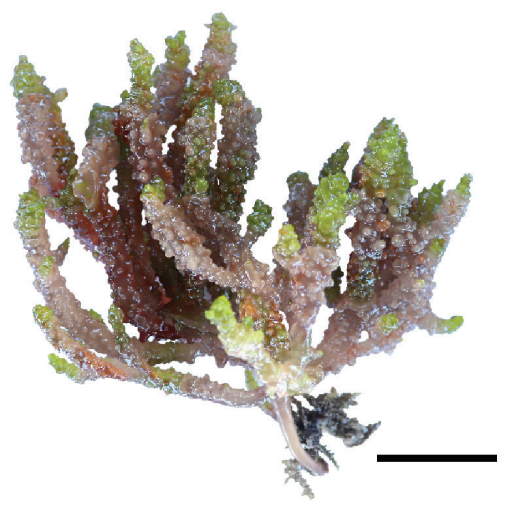

C

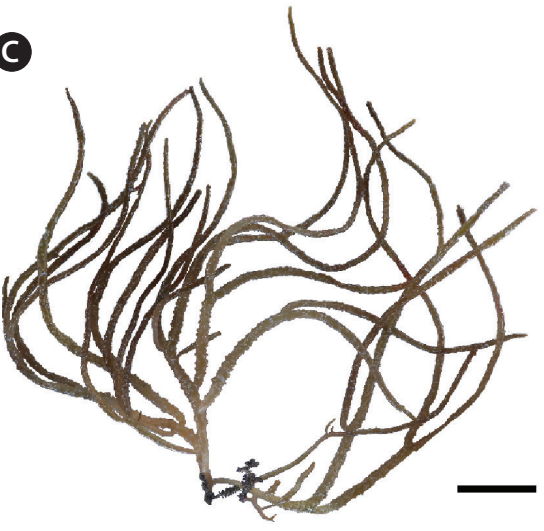

E

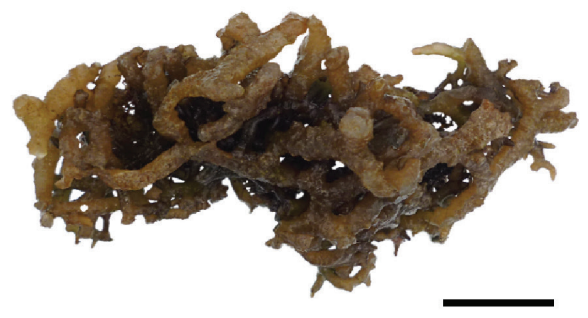

G

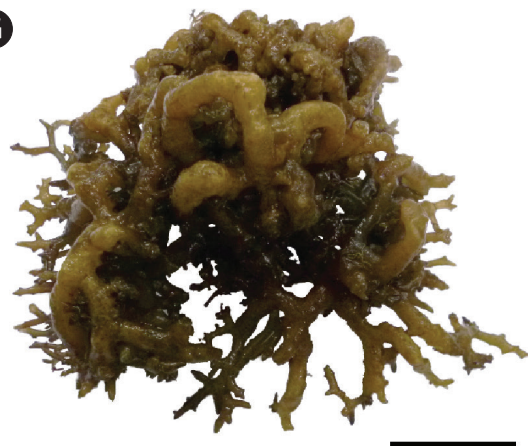

B

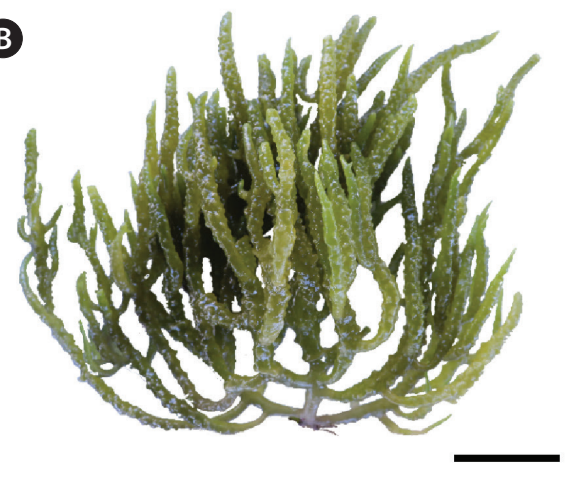

D

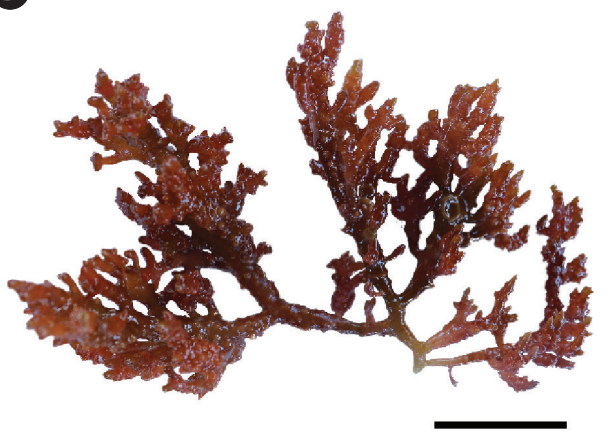

$\boldsymbol{F}$

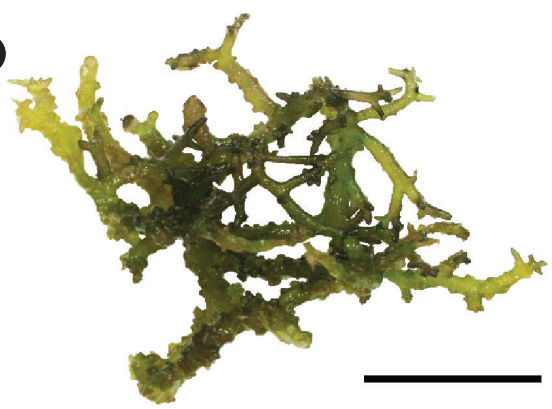

$\boldsymbol{\Theta}$

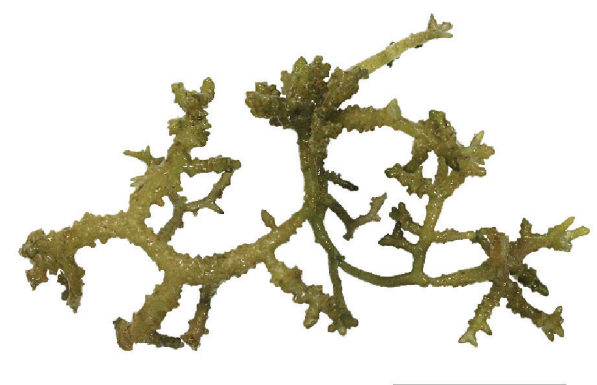

Fig. 2. Representative specimens of wild Kappaphycus used in this study. K. alvarezii specimens from Guiuan, Eastern Samar: (A) SamW-004, (B) SamW-023, (C) SamW-034, and (D) SamW-013. K. striatus specimens from Bolinao, Pangasinan: (E) MAL7, (F) SIL17, (G) MAL27, and (H) MAL19. Scale bars represent: $5 \mathrm{~cm}$. 


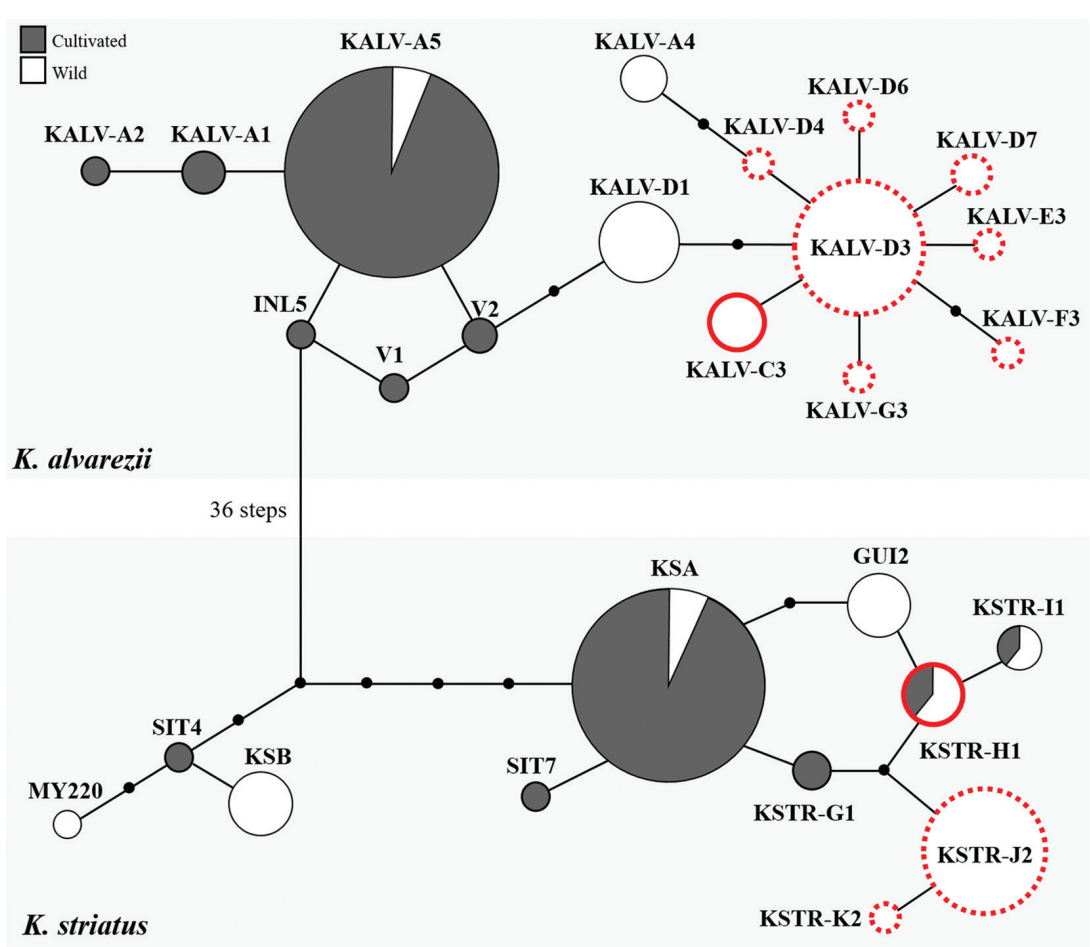

Fig. 3. Statistical parsimony haplotype network based on the concatenated COI-5P-cox2-3 spacer sequences. Lines indicate point mutations. Small black circles represent missing haplotypes. Red borders represent haplotypes identified in this study. Dotted borders denote novel haplotypes. Symbol size approximate number of individual sequences from this study and from published literature (Lim et al. 2014, Dumilag et al. 2016a, 2016b).

ed from the same site (Dumilag et al. 2016a). The majority of our K. alvarezii samples belonged to the previously reported KALV-D haplotype (Dumilag et al. 2016b). Aside from these, we identified three novel haplotypes from $K$. alvarezii-KALV-E $(\mathrm{n}=1)$, KALV-F $(\mathrm{n}=1)$, and KALV-G $(\mathrm{n}$ $=1$ ), which are different from the Southeast Asian farmed haplotype KALV-A (Indonesia, Malaysia, Philippines, and Vietnam) (Lim et al. 2014, Dumilag et al. 2016a) by three, four and two bp, respectively. Meanwhile, four of our K. striatus were identified as a known haplotype KSTRH (Dumilag et al. 2016a, 2016b). The majority of our $K$. striatus samples represent a new haplotype KSTR-J ( $\mathrm{n}=$ 25), which has a single base pair difference from KSTR-H, and a 2-bp difference from KSTR-A, a commercial haplotype from Southeast Asia (Lim et al. 2014, Dumilag et al. 2016a). Another novel haplotype, KSTR-K, was identified from one $K$. striatus sequence with a single base pair difference from KSTR-J.

Based on the cox2-3 spacer dataset, our K. alvarezii and $K$. striatus samples were distributed into four and two haplotypes, respectively (Supplementary Fig. S5). Thirty-six K. alvarezii sequences were found to be identical to previously known haplotype KALV-3 whereas one sequence matched haplotype KALV-4, both of which were previously identified from the wild $K$. alvarezii from Guiuan, Eastern Samar (Dumilag et al. 2016a). Two new $K$. alvarezii haplotypes were also recognized: KALV-5 $(\mathrm{n}=1)$ and KALV-6 $(n=3)$. These haplotypes were 1-bp different from KALV-3 and 2-bp different from KALV-4 haplotypes and the widely cultivated $K$. alvarezii haplotype 3 (Zuccarello et al. 2006, De Barros-Barreto et al. 2013, Halling et al. 2013, Lim et al. 2014, Dumilag et al. 2016a). Haplotypes KALV-3, KALV-4, KALV-5, and KALV-6, appeared to be biogeographically localized in Guiuan, Eastern Samar as they form a moderately supported subclade. On the other hand, four newly generated $K$. striatus sequences were shown to be identical to haplotype 89 , which is a widely distributed commercial $K$. striatus haplotype, reported from Southeast Asia (Zuccarello et al. 2006, Lim et al. 2014, Dumilag et al. 2016a, 2016b). A new haplotype denoted as KSTR-1 $(n=26)$ was observed for most of the sequences, which has a single base pair difference from haplotype 89.

For the concatenated COI-5P-cox2-3 spacer dataset, our K. alvarezii and K. striatus samples were grouped into eight and three haplotypes, respectively (Fig. 3). Three $K$. 
alvarezii sequences were identical to KALV-C3, which was previously reported from the same locality in Guiuan, Eastern Samar (Dumilag et al. 2016a). The majority of our $K$. alvarezii samples clustered together, forming a novel haplotype KALV-D3 $(n=27)$, which is 5 bp different from KALV-A5, the most widely cultivated haplotype in Southeast Asia (Lim et al. 2014, Dumilag et al. 2016a). Five other new haplotypes: KALV-D4 $(\mathrm{n}=1)$, KALV-D6 ( $\mathrm{n}$ $=1)$, KALV-D7 $(\mathrm{n}=3)$, KALV-E3 $(\mathrm{n}=1)$, and KALV-G3 $(\mathrm{n}=$ 1) were a single bp different from KALV-D3. Additionally, a seventh novel haplotype, KALV-F3 ( $\mathrm{n}=1)$, was 2-bp different from KALV-D3. For K. striatus, four of our samples were identical to the previously reported KSTR-H1 haplotype (Dumilag et al. 2016a, 2016b). Most K. striatus (n = 25) samples formed a novel haplotype, KSTR-J2, 3-bp different from the farmed haplotype KSA (Lim et al. 2014, Dumilag et al. 2016a). Lastly, one sequence was distinct from KSTR-J2 by $1 \mathrm{bp}$, forming a separate haplotype KSTR-K2.

\section{DISCUSSION}

The present study confirms the presence of $K$. striatus in Bolinao, as reported by Trono and Ohno (1992). Currently, there is only one wild Kappaphycus sequence from the area that is deposited in the database $-r b c L$ gene from a presumptive $K$. cottonii (Aguilan et al. 2003), which is most likely a K. striatus as it is identical to the Malaysian farmed K. striatus variety 'Yellow Flower' (Tan et al. 2012). Thus, this study confirms that the native species found in Bolinao is K. striatus. The occurrence of other Kappaphycus species is yet to be reported. This study is the first report on the haplotypes of wild $K$. striatus in the area. Most of our $K$. striatus samples belonged to two novel haplotypes distinct from the commercial haplotype KSA (Lim et al. 2014, Dumilag et al. 2016a, 2016b). However, several of our samples were identified as KSTR-H1, which was first reported from a variety ('Vanguard') farmed in Sitangkai, Tawi-Tawi, in the southern part of the Philippines (Dumilag et al. 2016a), and later identified in both farmed and wild-collected samples from Tagana-an, Surigao del Norte (Dumilag et al. 2016b). It is important to note that test planting of various eucheumatoid varieties, including 'Sacol' (K. striatus), was recently conducted in 2012 in Bolinao (Ganzon-Fortes 2016). Unfortunately, the report did not specify which specific strains were outplanted; thus, we cannot ascertain whether the wildcollected samples of haplotype KSTR-H1 are native to the area. However, the test farm site in 2012 was situated 500 $\mathrm{m}$ west of Silaqui Island while our collection sites are 1.5 $\mathrm{km}$ (Silaki Islet reef flat) and $2 \mathrm{~km}$ (Malilnep) east of Silaqui Island. Furthermore, the two sites are separated by a channel with strong current. Thus, the validity of all samples being wild is possible. However, this argument needs further investigation considering that remnants or fragments of cultivated specimens could be displaced from farms and have the potential to grow and establish themselves in the wild (Halling et al. 2013, Tano et al. 2015).

The present study also expands our knowledge on the diversity of wild $K$. alvarezii with the identification of seven novel haplotypes. These haplotypes are genetically dissimilar to the commercially farmed $K$. alvarezii haplotype KALV-A5 (Lim et al. 2014, Dumilag et al. 2016a). Nabalikad Reef, where the wild $K$. alvarezii samples from Guiuan, Eastern Samar were collected, is $7.5 \mathrm{~km}$ away from the closest farming sites, and no prior farming activities were recorded proximate to the reef area. These novel $K$. alvarezii haplotypes, along with the previously reported KALV-A4 and KALV-C3 (Dumilag et al. 2016a), seem to be biogeographically localized in Guiuan, Eastern Samar and are most closely related to KALV-D1, a haplotype previously reported from wild individuals in Tagana-an, Surigao del Norte (Dumilag et al. 2016b), which is about $150 \mathrm{~km}$ south of our collection site.

Based on the concatenated COI-5P-cox2-3 spacer sequences, there are now $19 \mathrm{~K}$. alvarezii and $12 \mathrm{~K}$. striatus haplotypes identified (Lim et al. 2014, Dumilag et al. $2016 a, 2016 b$ ). Despite the abundance of reported Kappaphycus haplotypes, only 14 of these (including the $K$. malesianus haplotype MY216 from Lim et al. 2014) represent cultivated varieties worldwide, with haplotypes KALV-A5 (haplotype 3 for cox2-3 spacer of $K$. alvarezii) and KSA (haplotype 89 for cox2-3 spacer of K. striatus) comprising the bulk of farmed haplotypes (Zuccarello et al. 2006, De Barros-Barreto et al. 2013, Halling et al. 2013, Lim et al. 2014, Dumilag et al. 2016a, 2016b) (Supplementary Fig. S5). This is not surprising since the majority of the globally farmed Kappaphycus originated from seed stocks sourced from the Philippines and vegetatively reproduced in farms, resulting in almost uniform genotypic composition of farmed varieties (at least based on commonly used markers). This could present increased risks of farm-wide infection and infestation, which could potentially spread on a global scale since most of the world's farmed Kappaphycus are clones.

The susceptibility of crops to diseases and mass infestations can be mitigated by increasing their genetic diversity (Storkey et al. 2018). A recent meta-analysis shows that cultivar mixtures had higher resistance to both biotic 
and abiotic stressors, resulting to higher yields compared to their monoculture counterparts (Reiss and Drinkwater 2018). The same was observed in agricultural systems where the host's genetic diversity prevented the spread of parasites in a meta-analysis of a diverse range of hosts and parasites interaction (Ekroth et al. 2019). This emphasizes the need to tap into the underutilized potential of the Kappaphycus gene pool for crop improvement.

Variation in the mitochondrial markers used in this study was unable to establish a link between genetics and morphology (Zuccarello et al. 2006, Milstein et al. 2008, Teasdale and Klein 2010, Ratnawati et al. 2020). Plasticity in response to abiotic and biotic factors produces a wide range of gross morphologies within a species (Doty 1988, Leliaert et al. 2014) and from our observations, this seemed to obscure the relationship between genotype and phenotype in our samples. For example, the high grazing pressure and challenging environmental conditions most likely contributed to the encrusting growth form of the wild K. striatus collected from Bolinao, Pangasinan, which upon cultivation in mesocosm tanks changed its morphology and growth form to that of typical of cultivated strains (Roleda personal observation). While these markers may be suitable for species identification and resolving interspecific relationship within Kappaphycus, employing genome-based assessments (e.g., microsatellites, single nucloetides, and genomewide association study) (Tablizo and Lluisma 2014, Li et al. 2018, Liu et al. 2019, Jia et al. 2020), in tandem with comprehensive morpho-phenotype analysis and crosstransplantation experiments is needed to resolve the drivers of variation in gross morphologies.

Interestingly, only $K$. striatus was collected from Bolinao, Pangasinan while only $K$. alvarezii was collected from Guiuan, Eastern Samar. Previous collection of wild Kappaphycus from Guiuan, Eastern Samar also reported only K. alvarezii from the area (Dumilag et al. 2016a). The reason behind this observation requires further investigation. We also found that our $K$. alvarezii collection is more genetically and morphologically diverse than our $K$. striatus collection. The small genetic variation observed in our $K$. striatus collection may have been caused by their less divergent cox2-3 spacer sequences, from which only six haplotypes were reported thus far (Lim et al. 2014, Dumilag et al. 2016a, 2016b). It is also possible that the low Kappaphycus diversity observed in Bolinao is caused by introduced strains from previous test plantings (Dawes et al. 1993, 1994, Ganzon-Fortes 2016) as there has been some evidence showing that introduced seaweeds can dominate a community, which may have an impact on the diversity of native species (Schaffelke and Hewitt 2007, Conklin et al. 2009, Halling et al. 2013).

Although the present study evaluated the genetic diversity of wild Kappaphycus strains in just two sites in the Philippines (Pangasinan and Eastern Samar), and with a relatively small dataset, the discovery of nine novel haplotypes suggests that wild populations of Kappaphycus in the Philippines still harbor unutilized strains. Considering the significant potentials of these new strains to help improve farm production, extensive efforts to characterize the genotypes of wild Kappaphycus strains are, therefore, warranted. The potentials of these wild strains to replace deteriorating farmed cultivars require further examination.

\section{ACKNOWLEDGEMENTS}

This is contribution no. 481 from the Marine Science Institute, University of the Philippines (UPMSI), Diliman. This work was funded by the UP System Enhanced Creative Work and Research Grant (ECWRG 2019-09-R) awarded to MYR, co-funded by the UKRI GCRF GlobalSeaweedSTAR programme (GSS/RF/015) awarded to MYR and RVD, and the UPMSI inhouse research grant to MYR. We thank the BFAR 8 Regional Director Juan D. Albaladejo and the staff for their hospitality in facilitating the collection of wild Kappaphycus samples in Guiuan, Eastern Samar. We also thank B. C. V. Narvarte, A. M. Tabonda, H. Dayao of UP-MSI and S. Damsik and J. Turong of MSU-TCTO for providing assistance during field works, sample processing, and initial laboratory experiments. MYR acknowledges the Department of Science and Technology (DOST) Balik Scientist Program (BSP) Fellowship. RVD acknowledges the DOST-Philippine Council for Agriculture, Aquatic, and Natural Resources Research and Development (PCAARRD) program, Establishment of Seaweed Research and Development Center (SeaRDeC) to Support the Seaweed Industry in BARMM, Project 2: Molecular characterization, selection, and production of high quality eucheumatoid cultivars in the Bangsamoro Autonomous Region in Muslim Mindanao.

\section{CONFLICTS OF INTEREST}

The authors declare that they have no potential conflicts of interest. 


\section{SUPPLEMENTARY MATERIALS}

Supplementary Table S1. Specimen information and GenBank accession numbers for all Kappaphycus species used in this study (https://www.e-algae.org).

Supplementary Table S2. Summary of external morphological characteristics of collected wild Kappaphycus species (https://www.e-algae.org).

Supplementary Fig. S1. Maximum likelihood (ML) tree of wild Kappaphycus sequences inferred from the mitochondrial $5^{\prime}$ region of the mitochondrial cytochrome $c$ oxidase subunit I gene (COI-5P) sequences (https:// www.e-algae.org).

Supplementary Fig. S2. Maximum likelihood (ML) tree of wild Kappaphycus sequences inferred from the mitochondrial cox2-3 spacer (https:/ /www.e-algae.org).

Supplementary Fig. S3. Maximum likelihood (ML) tree of wild Kappaphycus sequences inferred from the concatenated COI-5P-cox2-3 spacer sequences (https:// www.e-algae.org).

Supplementary Fig. S4. Statistical parsimony haplotype network based on the $5^{\prime}$ region of the mitochondrial cytochrome $c$ oxidase subunit I gene (COI-5P) sequences (https://www.e-algae.org).

Supplementary Fig. S5. Statistical parsimony haplotype network based on the cox2-3 spacer sequences (https://www.e-algae.org).

\section{REFERENCES}

Aguilan, J. T., Broom, J. E., Hemmingson, J. A., Dayrit, F. M., Montaño, M. N. E., Dancel, M. C. A., Niñonuevo, M. R. \& Furneaux, R. H. 2003. Structural analysis of carrageenan from farmed varieties of Philippine seaweed. Bot. Mar. 46:179-192.

Ask, E. I. \& Azanza, R. V. 2002. Advances in cultivation technology of commercial eucheumatoid species: a review with suggestions for future research. Aquaculture 206:257-277.

Azanza-Corrales, R. \& Ask, E. 2003. Kappaphycus alvarezii (Doty) Doty carposporeling growth and development in the laboratory. In Chapman, A. R. O., Anderson, A. J., Vreeland, V. I. \& Davidson, I. R. (Eds.) Proceedings of the 17th International Seaweed Symposium. Oxford University Press, Oxford, pp. 95-99.

Bixler, H. J. \& Porse, H. 2011. A decade of change in the seaweed hydrocolloids industry. J. Appl. Phycol. 23:321335.

Clement, M., Posada, D. \& Crandall, K. A. 2000. TCS: a com- puter program to estimate gene genealogies. Mol. Ecol. 9:1657-1659.

Conklin, K. Y., Kurihara, A. \& Sherwood, A. R. 2009. A molecular method for identification of the morphologically plastic invasive algal genera Eucheuma and Kappaphycus (Rhodophyta, Gigartinales) in Hawaii. J. Appl. Phycol. 21:691-699.

Dawes, C. J., Lluisma, A. O. \& Trono, G. C. 1994. Laboratory and field growth studies of commercial strains of $\mathrm{Eu}$ cheuma denticulatum and Kappaphycus alvarezii in the Philippines. J. Appl. Phycol. 6:21-24.

Dawes, C. J., Trono, G. C. Jr. \& Lluisma, A. O. 1993. Clonal propagation of Eucheuma denticulatum and Kappaphycus alvarezii for Philippine seaweed farms. Hydrobiologia 260-261:379-383.

De Barros-Barreto, M. B. B., Marinho, L. C., Reis, R. P., da Mata, C. S. \& Ferreira, P. C. G. 2013. Kappaphycus alvarezii (Gigartinales, Rhodophyta) cultivated in Brazil: is it only one species? J. Appl. Phycol. 25:1143-1149.

Doty, M. S. 1973. Farming the red seaweed, Eucheuma for carrageenans. Micronesica 9:59-73.

Doty, M. S. 1985. Eucheuma alvarezii, sp. nov. (Gigartinales, Rhodophyta) from Malaysia. In Abbott, I. A. \& Norris, J. N. (Eds.) Taxonomy of Economic Seaweeds: With Reference to Some Pacific and Caribbean Species. California Sea Grant College Program, La Jolla, CA, pp. 37-45.

Doty, M. S. 1988. Prodomus Ad Systematica Eucheumatoideorum: a tribe of commercial seaweeds related to Eucheuma (Solieriaceae, Gigartinales). In Abott, I. A. (Ed.) Taxonomy of Economic Seaweeds: With Reference to Some Pacific and Caribbean Species. California Sea Grant Program, La Jolla, CA, pp. 47-61.

Dumilag, R. V., Gallardo, W. G. M., Garcia, C. P. C., You, Y., Chaves, A. K. G. \& Agahan, L. 2017. Phenotypic and mtDNA variation in Philippine Kappaphycus cottonii (Gigartinales, Rhodophyta). Mitochondrial DNA A DNA Mapp. Seq. Anal. 29:951-963.

Dumilag, R. V. \& Lluisma, A. O. 2014. Resolving the phylogenetic affinities of Kappaphycus inermis within the genus Kappaphycus (Gigartinales, Solieriaceae) using mitochondrial and plastid markers. Phytotaxa 162:223-231.

Dumilag, R. V., Orosco, F. L. \& Lluisma, A. O. 2016a. Genetic diversity of Kappaphycus species (Gigartinales, Rhodophyta) in the Philippines. Syst. Biodivers. 14:441-451.

Dumilag, R. V., Salvador, R. C. \& Halling, C. 2016b. Genotype introduction affects population composition of native Philippine Kappaphycus (Gigartinales, Rhodophyta). Conserv. Genet. Resour. 8:439-441.

Ekroth, A. K. E., Rafaluk-Mohr, C. \& King, K. C. 2019. Host genetic diversity limits parasite success beyond agricul- 
tural systems: a meta-analysis. Proc. R. Soc. B Biol. Sci. 286:20191811.

Ganzon-Fortes, E. T. 2016. Sea out-planting and seedstock production of laboratory generated carrageenophyte cultivars. Technical Report submitted to the Philippine Council for Agricultural and Aquatic Resources Research and Development, PCAARRD. The Marine Science Institute, College of Science, University of the PhilippinesDiliman, 7 pp.

Halling, C., Wikström, S. A., Lilliesköld-Sjöö, G., Mörk, E., Lundsør, E. \& Zuccarello, G. C. 2013. Introduction of Asian strains and low genetic variation in farmed seaweeds: indications for new management practices. J. Appl. Phycol. 25:89-95.

Harlan, J. R. \& de Wet, J. M. J. 1971. Toward a rational classification of cultivated plants. Taxon 20:509-517.

Hayashi, L., Reis, R. P., Dos Santos, A. A., Castelar, B., Robledo, D., De Vega, G. B., Msuya, F. E., Eswaran, K., Yasir, S. M., Ali, M. K. M. \& Hurtado, A. Q. 2017. The cultivation of Kappaphycus and Eucheuma in tropical and sub-tropical waters. In Hurtado, A. Q., Critchley, A. T. \& Neish, I. C. (Eds.) Tropical Seaweed Farming Trends, Problems and Opportunities: Focus on Kappaphycus and Eucheuma of Commerce. Springer, Cham, pp. 55-90.

Hinaloc, L. A. R. 2017. In vitro carpospore recruitment and germling growth in Kappaphycus alvarezii (Doty) Doty ex P.C. Silva (Rhodophyta: Gigartinales). M.Sc. thesis. University of the Philippines, Diliman, $73 \mathrm{pp}$.

Hurtado, A. Q. \& Biter, A. B. 2007. Plantlet regeneration of Kappaphycus alvarezii var. adik-adik by tissue culture. J. Appl. Phycol. 19:783-786.

Hurtado, A. Q. \& Cheney, D. P. 2003. Propagule production of Eucheuma denticulatum (Burman) Collins et Harvey by tissue culture. Bot. Mar. 46:338-341.

Jia, S., Wang, G., Liu, G., Qu, J., Zhao, B., Jin, X., Zhang, L., Yin, J., Liu, C., Shan, G., Wu, S., Song, L., Liu, T., Wang, X. \& Yu, J. 2020. High-quality de novo genome assembly of Kappaphycus alvarezii based on both PacBio and HiSeq sequencing. Available from: https://www.biorxiv.org/co ntent/10.1101/2020.02.15.950402v1.full.pdf. Accessed Mar 28, 2020.

Kumar, S., Stecher, G. \& Tamura, K. 2016. MEGA7: Molecular Evolutionary Genetics Analysis version 7.0 for bigger datasets. Mol. Biol. Evol. 33:1870-1874.

Largo, D. B., Chung, I. K., Phang, S. -M., Gerung, G. S. \& Sondak, C. F. A. 2017. Impacts of climate change on Eucheuma-Kappaphycus farming. In Hurtado, A. Q., Critchley, A. T. \& Neish, I. C. (Eds.) Tropical Seaweed Farming Trends, Problems and Opportunities: Focus on Kappaphycus and Eucheuma of Commerce. Springer, Cham, pp. 121-129.

Leliaert, F., Verbruggen, H., Vanormelingen, P., Steen, F., López-Bautista, J. M., Zuccarello, G. C. \& De Clerck, O. 2014. DNA-based species delimitation in algae. Eur. J. Phycol. 49:179-196.

Li, D., Pfeiffer, T. W. \& Cornelius, P. L. 2007. Soybean QTL for yield and yield components associated with Glycine soja alleles. Crop Sci. 48:571-581.

Li, Y., Liu, N., Wang, X., Tang, X., Zhang, L., Meinita, M. D. N., Wang, G., Yin, H., Jin, Y., Wang, H., Liu, C., Chi, S., Liu, T. \& Zhang, J. 2018. Comparative genomics and systematics of Betaphycus, Eucheuma, and Kappaphycus (Solieriaceae: Rhodophyta) based on mitochondrial genome. J. Appl. Phycol. 30:3435-3443.

Lim, P. E., Tan, J., Phang, S. M., Nikmatullah, A., Hong, D. D., Sunarpi, H. \& Hurtado, A. Q. 2014. Genetic diversity of Kappaphycus Doty and Eucheuma J. Agardh (Solieriaceae, Rhodophyta) in Southeast Asia. J. Appl. Phycol. 26:1253-1272.

Liu, N., Zhang, L., Tang, X., Wang, X., Meinita, M. D. N., Wang, G., Chen, W. \& Liu, T. 2019. Complete plastid genome of Kappaphycus alvarezii: insights of large-scale rearrangements among Florideophyceae plastid genomes. J. Appl. Phycol. 31:3997-4005.

Luhan, M. R. J. \& Mateo, J. P. 2017. Clonal production of Kappaphycus alvarezii (Doty) Doty in vitro. J. Appl. Phycol. 29:2339-2344.

Luhan, M. R. J. \& Sollesta, H. 2010. Growing the reproductive cells (carpospores) of the seaweed, Kappaphycus striatum, in the laboratory until outplanting in the field and maturation to tetrasporophyte. J. Appl. Phycol. 22:579585.

Maxted, N., Ford-Lloyd, B. V., Jury, S., Kell, S. \& Scholten, M. 2006. Towards a definition of a crop wild relative. Biodivers. Conserv. 15:2673-2685.

Milstein, D., Oliveira, M. C., Martins, F. M. \& Matioli, S. R. 2008. Group I introns and associated homing endonuclease gene reveals a clinal structure for Porphyra spiralis var. amplifolia (Bangiales, Rhodophyta) along the Eastern coast of South America. BMC Evol. Biol. 8:308.

Munns, R., James, R. A., Xu, B., Athman, A., Conn, S. J., Jordans, C., Byrt, C. S., Hare, R. A., Tyerman, S. D., Tester, M., Plett, D. \& Gilliham, M. 2012. Wheat grain yield on saline soils is improved by an ancestral $\mathrm{Na}+$ transporter gene. Nat. Biotechnol. 30:360-364.

Parker, H. S. 1974. The culture of red alga genus Eucheuma in the Philippines. Aquaculture 3:425-439.

Prischmann, D. A., Dashiell, K. E., Schneider, D. J. \& Eubanks, M. W. 2009. Evaluating Tripsacum-introgressed maize germplasm after infestation with western corn root- 
worms (Coleoptera: Chrysomelidae). J. Appl. Entomol. 133:10-20.

Ratnawati, P., Simatupang, N. F., Pong-Masak, P. R., Paul, N. A. \& Zuccarello, G. C. 2020. Genetic diversity analysis of cultivated Kappaphycus in Indonesian seaweed farms using COI gene. Squalen Bull. Mar. Fish. Postharvest Biotechnol. 15:65-72.

Reiss, E. R. \& Drinkwater, L. E. 2018. Cultivar mixtures: a meta-analysis of the effect of intraspecific diversity on crop yield. Ecol. Appl. 28:62-77.

Robinson, N., Winberg, P. \& Kirkendale, L. 2013. Genetic improvement of macroalgae: status to date and needs for the future. J. Appl. Phycol. 25:703-716.

Rodrigora, L. D. 2017. Laboratory tetraspore recruitment and early development in wild Kappaphycus alvarezii (Rhodophyta: Gigartinales) for farming. M.Sc. thesis. University of the Philippines, Diliman, 72 pp.

Roleda, M. Y., Rodrigora-Calala, L. D., Hinaloc, L. A. R. \& Ganzon-Fortes, E. T. 2017. Red, blue, and green, and shades in between: diversity and plasticity in color expression in the life history of Kappaphycus. Phycologia 56:161.

Salvador, R. C. \& Serrano, A. E. 2005. Isolation of protoplasts from tissue fragments of Philippine cultivars of Kappaphycus alvarezii (Solieriaceae, Rhodophyta). J. Appl. Phycol. 17:15-22.

Saunders, G. W. 2005. Applying DNA barcoding to red macroalgae: a preliminary appraisal holds promise for future applications. Philos. Trans. R. Soc. Lond. B Biol. Sci. 360:1879-1888.

Schaffelke, B. \& Hewitt, C. L. 2007. Impacts of introduced seaweeds. Bot. Mar. 50:397-417.

Storkey, J., Bruce, T. J. A., McMillan, V. E. \& Neve, P. 2018. The future of sustainable crop protection relies on increased diversity of cropping systems and landscapes. In Lemaire, G., Cesar de Faccio Carvalho, P., Kronberg, S. \& Recous, S. (Eds.) Agroecosystem Diversity: Reconciling Contemporary Agriculture and Environmental Quality. Academic Press, London, pp. 199-209.

Tablizo, F. A. \& Lluisma, A. O. 2014. The mitochondrial genome of the red alga Kappaphycus striatus ("Green Sacol” variety): complete nucleotide sequence, genome structure and organization, and comparative analysis. Mar. Genomics 18:155-161.

Tamura, K. 1992. Estimation of the number of nucleotide substitutions when there are strong transition-transversion and G+C-content biases. Mol. Biol. Evol. 9:678-687.

Tan, J., Lim, P. -E. \& Phang, S. -M. 2013. Phylogenetic relationship of Kappaphycus Doty and Eucheuma J. Argardh (Solieraceae, Rhodophyta) in Malaysia. J. Appl. Phycol. 25:13-29.
Tan, J., Lim, P. -E., Phang, S. -M., Hong, D. D., Sunarpi, H. \& Hurtado, A. Q. 2012. Assessment of four molecular markers as potential DNA barcodes for red algae Kappaphycus Doty and Eucheuma J. Agardh (Solieriaceae, Rhodophyta). PLoS ONE 7:e52905.

Tano, S. A., Halling, C., Lind, E., Buriyo, A. \& Wikström, S. A. 2015. Extensive spread of farmed seaweeds causes a shift from native to non-native haplotypes in natural seaweed beds. Mar. Biol. 162:1983-1992.

Teasdale, B. W. \& Klein, A. S. 2010. Genetic variation and biogeographical boundaries within the red alga Porphyra umbilicalis (Bangiales, Rhodophyta). Bot. Mar. 53:417431.

Thompson, J. D., Higgins, D. G. \& Gibson, T. J. 1994. CLUSTAL W: improving the sensitivity of progressive multiple sequence alignment through sequence weighting, position-specific gap penalties and weight matrix choice. Nucleic Acids Res. 22:4673-4680.

Trono, G. C. Jr. 1974. Eucheuma farming in the Philippines. U.P. Natural Science Research Centre, Quezon City.

Trono, G. C. Jr. \& Largo, D. B. 2019. The seaweed resources of the Philippines. Bot. Mar. 62:483-498.

Trono, G. C. Jr. \& Ohno, M. 1992. Seaweeds collected from Bolinao, Pangasinan, Philippines. Bull. Mar. Sci. Fish. 12:39-50.

Vairappan, C. S., Chung, C. S., Hurtado, A. Q., Soya, F. E., Lhonneur, G. B. \& Critchley, A. 2008. Distribution and symptoms of epiphyte infection in major carrageenophyte-producing farms. J. Appl. Phycol. 20:477-483.

Valderrama, D., Cai, J., Hishamunda, N. \& Ridler, N. 2013. Social and economic dimensions of carrageenan seaweed farming. Fisheries and Aquaculture Technical Paper No. 580. Food and Agriculture Organization, Rome, 204 pp.

Valderrama, D., Cai, J., Hishamunda, N., Ridler, N., Neish, I. C., Hurtado, A. Q., Msuya, F. E., Krishnan, M., Narayanakumar, R., Kronen, M., Robledo, D., Gasca-Leyva, E. \& Fraga, J. 2015. The economics of Kappaphycus seaweed cultivation in developing countries: a comparative analysis of farming systems. Aquacult. Econ. Manag. 19:251-277.

Valero, M., Guillemin, M. -L., Detombe, C., Jacquemin B., Gachon, C. M. M., Badis, Y., Buschmann, A. H., Camus, C. \& Faugeron, S. 2017. Perspectives on domestication research for sustainable seaweed aquaculture. Perspect. Phycol. 4:33-46.

Xie, X., Jin, F., Song, M. -H., Suh, J. -P., Hwang, H. -G., Kim, Y. -G., McCouch, S. R. \& Ahn, S. -N. 2008. Fine mapping of a yield-enhancing QTL cluster associated with transgressive variation in an Oryza sativa $\times$ O. rufipogon cross. Theor. Appl. Genet. 116:613-622. 
Yunque, D. A. T., Tibubos, K. R., Hurtado, A. Q. \& Critchley, A. T. 2011. Optimization of culture conditions for tissue culture production of young plantlets of carrageenophyte Kappaphycus. J. Appl. Phycol. 23:433-438.

Zhang, H., Mittal, N., Leamy, L. J., Barazani, O. \& Song, B. -H. 2017. Back into the wild: apply untapped genetic diversity of wild relatives for crop improvement. Evol. Appl. 10:5-24.
Zuccarello, G. C., Burger, G., West, J. A. \& King, R. J. 1999. A mitochondrial marker for red algal intraspecific relationships. Mol. Ecol. 8:1443-1447.

Zuccarello, G. C., Critchley, A. T., Smith, J., Sieber, V., Lhonneur, G. B. \& West, J. A. 2006. Systematics and genetic variation in commercial Kappaphycus and Eucheuma (Solieriaceae, Rhodophyta). J. Appl. Phycol. 18:643-651. 